\title{
Influence of environmental and anthropogenic factors on the composition, concentration and spatial distribution of microplastics: A case study of the Bay of Brest (Brittany, France) ${ }^{\text {is }}$
}

\author{
L. Frère ${ }^{\text {a }}$, I. Paul-Pont ${ }^{\mathrm{a},}{ }^{*}$, E. Rinnert ${ }^{\mathrm{b}}$, S. Petton ${ }^{\mathrm{c}}$, J. Jaffré ${ }^{\mathrm{a}}$, I. Bihannic ${ }^{\mathrm{a}}$, P. Soudant ${ }^{\mathrm{a}}$, \\ C. Lambert ${ }^{a, 1}$, A. Huvet ${ }^{c, 1}$ \\ a LEMAR UMR 6539 CNRS/UBO/IRD/Ifremer, IUEM, rue Dumont d'Urville, 29280 Plouzané, France \\ ${ }^{\mathrm{b}}$ Ifremer, Laboratoire Détection, Capteurs et Mesures, Centre de Bretagne, ZI de la Pointe du Diable, CS 10070, 29280 Plouzané, France \\ ' Ifremer, LEMAR UMR 6539 CNRS/UBO/IRD/Ifremer, Centre de Bretagne, ZI de la Pointe du Diable, CS 10070, 29280 Plouzané, France
}

\section{A R T I C L E I N F O}

\section{Article history:}

Received 18 July 2016

Received in revised form

8 March 2017

Accepted 9 March 2017

\section{Keywords:}

Microplastic

Coastal ecosystem

Surface water

Sediment

Raman spectroscopy

Hydrodynamic

Dispersal particle modelling

\begin{abstract}
A B S T R A C T
The concentration and spatial distribution of microplastics in the Bay of Brest (Brittany, France) was investigated in two surveys. Surface water and sediment were sampled at nine locations in areas characterized by contrasting anthropic pressures, riverine influences or water mixing. Microplastics were categorized by their polymer type and size class. Microplastic contamination in surface water and sediment was dominated by polyethylene fragments (PE, 53-67\%) followed by polypropylene (PP, 16 $-30 \%$ ) and polystyrene (PS, 16-17\%) microparticles. The presence of buoyant microplastics (PE, PP and PS) in sediment suggests the existence of physical and/or biological processes leading to vertical transfer of lightweight microplastics in the bay. In sediment (upper $5 \mathrm{~cm}$ ), the percentage of particles identified by Raman micro-spectroscopy was lower (41\%) than in surface water (79\%) and may explain the apparent low concentration observed in this matrix $\left(0.97 \pm 2.08 \mathrm{MP} \mathrm{kg}^{-1}\right.$ dry sediment). Mean microplastic concentration was $0.24 \pm 0.35 \mathrm{MP} \mathrm{m}^{-3}$ in surface water. We suggest that the observed spatial MP distribution is related to proximity to urbanized areas and to hydrodynamics in the bay. A particle dispersal model was used to study the influence of hydrodynamics on surface microplastic distribution. The outputs of the model showed the presence of a transitional convergence zone in the centre of the bay during flood tide, where floating debris coming from the northern and southern parts of the bay tends to accumulate before being expelled from the bay. Further modelling work and observations integrating (i) the complex vertical motion of microplastics, and (ii) their point sources is required to better understand the fate of microplastics in such a complex coastal ecosystem.
\end{abstract}

๑) 2017 Elsevier Ltd. All rights reserved.

\section{Introduction}

Plastic pollution of the oceans represents an increasing concern for science and society. Global production of plastics has shown a steady increase since 1950, reaching 311 million tons in 2014 (PlasticsEurope, 2016). A recent study estimated that 99.5 million tons of plastic waste were generated in coastal regions in 2010 , and 4.8 to 12.7 million tons entered the oceans (Jambeck et al., 2015). Ironically, as a consequence of their benefits, specifically their

\footnotetext{
This paper has been recommended for acceptance by Eddy Y. Zeng

* Corresponding author.

E-mail address: ika.paulpont@univ-brest.fr (I. Paul-Pont).

1 These authors contributed equally to this work.
}

durability and resistance to degradation, plastics accumulate in marine environments and are now the primary constituent of marine debris (Barnes et al., 2009). Several trillion pieces of plastic are estimated to currently pollute the surface of the world's oceans, with microplastics (MP) representing 92\% (Eriksen et al., 2014; Sebille et al., 2015). These MP, defined as items $\leq 5 \mathrm{~mm}$ diameter (Arthur et al., 2009) are introduced into aquatic environments by many pathways. They can be divided into two categories: primary MP that directly enter the oceans as micro-sized particles (e.g. cosmetics, synthetic fibres, pre-production pellets), and secondary MP which result from the breakdown of larger plastic items due to a combination of environmental factors (physical, chemical and biological processes) and the properties of the polymer in question (Browne et al., 2007; Fendall and Sewell, 2009). 
Microplastics have been reported in the Pacific (Eriksen et al., 2013; Moore et al., 2001), Atlantic (Ivar do Sul et al., 2013; Law et al., 2010) and Indian Oceans (Ogata et al., 2009), as well as in the Mediterranean (Collignon et al., 2012; Vianello et al., 2013) and North Seas (Claessens et al., 2011; Dubaish and Liebezeit, 2013) and in Arctic polar waters (Lusher et al., 2015). They have contaminated all environmental matrices: surface water (Eriksen et al., 2013; Moore et al., 2001), water column (Lattin et al., 2004; Ng and Obbard, 2006), sediment (Van Cauwenberghe et al., 2013; Vianello et al., 2013) and biota (Devriese et al., 2015; Fossi et al., 2012; Lusher et al., 2013; Murray and Cowie, 2011). These previous studies demonstrate that the entire marine ecosystem is contaminated by MP (Lusher, 2015; Wright et al., 2013). In addition to their physical impacts on marine biota (reviewed in Wright et al., 2013; Rochman et al., 2016) MP may represent a threat for marine life as they can leach toxic chemicals from plastic additives and adsorbed pollutants such as metals, pesticides or Persistent Organic Pollutants (POP) (Ashton et al., 2010; Fossi et al., 2014; Ogata et al., 2009; Teuten et al., 2009) when incorporated in the marine food chain (Avio et al., 2015; Fossi et al., 2012). Whether the transfer and impact of POP adsorbed on MP are of any importance is, however, a subject of debate (Koelmans et al., 2016; Paul-Pont et al., 2016). Furthermore, MP subjected to biofouling and colonization by prokaryotic and eukaryotic organisms (Zettler et al., 2013) can potentially serve as vehicles that disperse harmful and/or exotic species (Goldstein et al., 2014), or serve as reservoirs for pathogen transmission, thereby threatening marine life.

At the European level, the Marine Strategy Framework Directive (MSFD) has defined marine litter as a full descriptor of the quality of the marine environment with a focus on MP and their degradation products as a main issue (Galgani et al., 2014). In this context, studies aiming to determine the extent and impact of this pollution should be interpreted in a local geographical, physical and socioeconomic context. The aim of the present study was to evaluate MP contamination in the Bay of Brest (Brittany, France), which is a rich and diverse ecosystem in terms of habitats, flora and fauna, and is also at the centre of many human activities. Additionally, this study investigated the influence of anthropogenic activities and environmental conditions on the spatial and temporal distribution of MP in surface water and sediment across a complex coastal ecosystem. The data are discussed with reference to a particle dispersal model based on realistic hydrodynamic characteristics, simulating particle distribution throughout the Bay of Brest.

\section{Material and methods}

\subsection{Study area: hydrological characteristics}

The Bay of Brest $\left(180 \mathrm{~km}^{2}\right)$ is a shallow, semi-enclosed marine ecosystem on the western coast of Europe (France), linked to the Iroise Sea through a narrow strait (the Goulet) which is $1.8 \mathrm{~km}$ wide and $\sim 50 \mathrm{~m}$ deep (Fig. 1). This is a shallow ecosystem, as $53 \%$ of the surface of the bay has a depth below $5 \mathrm{~m}$. Only $13 \%$ of the total area is deeper than $20 \mathrm{~m}$ and the maximum depth is around $50 \mathrm{~m}$ at the Goulet (Auffret, 1983). More than 63\% of the freshwater supply in the Bay originates from the Aulne river (surface area: $1842 \mathrm{~km}^{2}$ ), 15\% from the Elorn river: $\left(403 \mathrm{~km}^{2}\right.$ ) and 5\% from the Mignonne river $\left(115 \mathrm{~km}^{2}\right.$ ) (Auffret, 1983). To give a sense of relative scale, the total annual river discharge is equivalent to the volume exchanged with the ocean during a single tidal period (Le Pape et al., 1996). Tidal currents influence the hydrodynamics of the bay while wave action has a limited influence. This macrotidal system, with an average tide amplitude of $4.7 \mathrm{~m}$, exchanges one-third of its water (around a billion cubic metres) twice a day with the Iroise Sea, with renewal of only $\sim 15 \%$ of its waters (Auffret, 1983).

\subsection{Sampling method}

Nine locations were selected to investigate microplastic concentration, based on specific anthropogenic activities and environmental conditions (Fig. 1). Three of these sites were located in the most urbanized area of the Bay of Brest (Brest urban density: 2815 people per $\mathrm{km}^{2}$; Institut National de la Statistique et des Etudes Economiques (INSEE, 2013)). These places are characterized by intense anthropogenic activity: site A1 was located at the junction of the recreational and military harbours; site A2 was located near the exit of the three harbours (recreational, military and commercial); and site A3 was close to the outflow of a wastewater treatment plant (WWTP). The next three sites were selected in areas subject to freshwater inputs, at the mouths of the Elorn (site E1), the Mignonne (site E2) and the Aulne (site E3) rivers. The last three stations were located in areas known to have a mix of water from different origins: between the Iroise Sea and the centre of the bay for site M1, between the centre and the southern part of the bay for site M2, and within the southern part of the bay for site M3.

The microplastic contamination of the Bay of Brest was assessed in two environmental matrices (surface water and sediment) sampled at the nine stations during two sampling surveys conducted in 2014. Surface water samples were collected in spring (16-24 April 2014) and in autumn (26 September to 3 October 2014). Sediment samples were obtained in winter (25 February to $11 \mathrm{March}$ ) and in autumn (17 and 20 October 2014). Environmental conditions prior to sampling are detailed in Supplementary Table S1.

To study MP occurrence in surface waters, the top $20 \mathrm{~cm}$ of the water was sampled using a standard Manta trawl with a $335 \mu \mathrm{m}$ mesh net and a rectangular net opening of $0.6 \times 0.16 \mathrm{~m}$, aboard the research vessel Hesione at an average speed of three knots for $20 \mathrm{~min}$. To avoid the net riding on waves that may lead to variability in the water flow through the net and wind-induced column water mixing, surface water collection was conducted when wind velocity was below $5 \mathrm{~m} \mathrm{~s}^{-1}$, with a Beaufort Sea Scale between 0 and 2 . Sampling was systematically undertaken against the current flow at ebb tide, as the water flowed out of the bay. Two flow meters (model 23.091, KC Denmark Research Equipment and model 2030, General Oceanics) were used to evaluate the volume of seawater filtered through the net. These machines were carefully intercalibrated to ensure a reliable comparison of the two sets of measures. The net was thoroughly rinsed with seawater to concentrate debris in the cod end, and samples were transferred into screw capped glass jars. The sediment samples were collected in triplicate at each station using a Van Veen grab deployed from the research vessel Albert Lucas. The sublayer (top $5 \mathrm{~cm}$ ) of each replicate was collected by opening the upper trap of the Van Veen grab, and the triplicates were then mixed to get approximately $3 \mathrm{~L}$ of wet sediment per station. Samples were stored in screw-capped glass jars. All samples were stored at $-20{ }^{\circ} \mathrm{C}$ until analysis.

\subsection{Visual particle sorting and Raman spectroscopic analysis}

For surface water samples, items of marine debris $>5 \mathrm{~mm}$ were manually removed and were rinsed with distilled water in order to collect potential MP attached to their surface. Particles $<5 \mathrm{~mm}$, visible to the naked eye, were collected using clean tweezers. The remaining samples were vacuum filtered on fiberglass filters (90 mm diameter; $1.6 \mu \mathrm{m}$ mesh) and microparticles were sorted and removed under a dissecting stereomicroscope (Leica MZ6 with a 6:3:1 zoom magnification changer). For sediment samples, a density separation was performed to separate MP (density $0.8-1.4 \mathrm{~g} \mathrm{~cm}^{-3}$ ) from denser natural particles such as sand and 


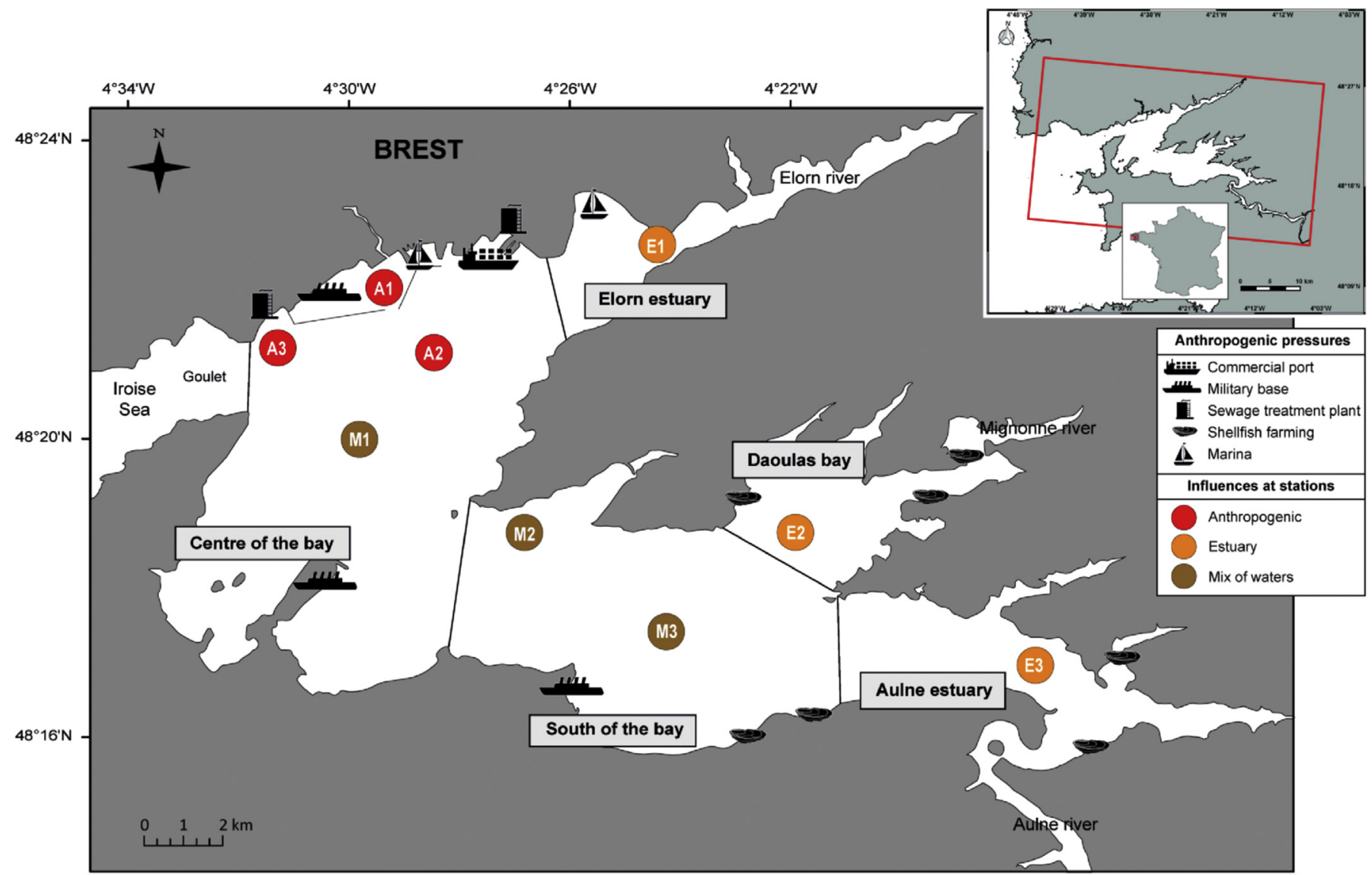

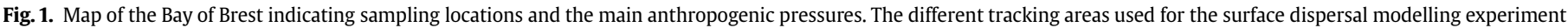

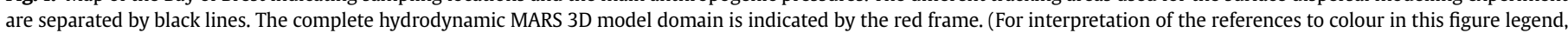
the reader is referred to the web version of this article.)

coarse sediment grains $\left(\sim 2.65 \mathrm{~g} \mathrm{~cm}^{-3}\right)$ (Hidalgo-Ruz et al., 2012). Three density separations were made: the first two used a concentrated saline $\mathrm{NaCl}$ solution $\left(1.2 \mathrm{~g} \mathrm{~cm}^{-3}\right)$ while the last used a sodium tungstate solution $\left(1.56 \mathrm{~g} \mathrm{~cm}^{-3}\right)$. Supernatants were collected and vacuum filtered (fiberglass filters of $90 \mathrm{~mm}$ with $1.6 \mu \mathrm{m}$ pore size), and particles were sorted using a dissecting binocular microscope. Using this method, the size of the smallest identified particles was $131 \times 87 \mu \mathrm{m}$ for sediment samples and $148 \times 108 \mu \mathrm{m}$ for surface water samples. To validate the sediment MP extraction method that used sodium tungstate, a spiking experiment was performed to verify the full recovery of denser plastics. Ten particles $(<5 \mathrm{~mm})$ of each polymer type, PVC $\left(1.4 \mathrm{~g} \mathrm{~cm}^{-3}\right)$, PET $\left(1.3-1.4 \mathrm{~g} \mathrm{~cm}^{-3}\right)$ and PA $\left(1.02-1.13 \mathrm{~g} \mathrm{~cm}^{-3}\right)$ (Goodfellow, France), were spiked into sediment collected from the Bay of Brest. A 100\% recovery was observed for all tested plastics without any impairment in the identification of the polymers by Raman spectroscopy (data not shown).

All sorted particles were counted and their shape (fragments, pellets, films, foams and fibres) was described before spectroscopic analysis. Particles were analysed using a HORIBA Scientific LabRam HR800 Raman micro-spectrometer (Villeneuve d'Ascq, France) equipped with an Oxxium laser (Lannion, France) set at $785 \mathrm{~nm}$ and a $10 \times$ Olympus objective (NA $=0.25$ ). A semi-automated Raman micro-spectroscopy method was used to characterize each particle by its morphology and molecular composition (Frère et al., 2016). Floating microplastic data were reported in units of microplastic per cubic metre $\left(\mathrm{MP} \mathrm{m}^{-3}\right)$, while sediment MP data were expressed as units of microplastic per dry weight (MP kg $\left.{ }^{-1} \mathrm{DW}\right)$. Microplastic data were also expressed in units of mass per $\mathrm{m}^{3}$ (water sample) or mass per $\mathrm{kg}$ (sediment sample) in the text and in Supplementary Table S2. To facilitate comparison with other studies, the data were also expressed as units per $\mathrm{km}^{2}$ (water sample) or units per litre (sediment sample) (Supplementary Table S2).

\subsection{Background contamination}

To reduce contamination from airborne particles, glass material was used and all equipment was rinsed twice with distilled water, followed by a onetime rinse with $70 \%$ ethanol before being immediately covered. Operators wore cotton lab coats at all times, but no gloves because these tend to fix airborne particles such as fibres. All surfaces were cleaned with $70 \%$ ethanol and operators washed their hands frequently. To assess residual airborne particle contamination not prevented by our operating precautions, empty glass jars were left open during the sampling activities (for both surface water and sediment sampling). Similarly, procedural blanks were run at all steps of the sample analyses with empty glass jars left open during the procedures. Each procedural blank jar was then rinsed with distilled water followed by vacuum filtration on fiberglass filters (90 mm diameter; $1.6 \mu \mathrm{m}$ mesh) and quantification of particle contamination.

\subsection{Surface dispersal modelling}

The dynamics of surface microplastics in the Bay of Brest were modelled using the free Java tool Ichthyop v3.2 (Lett et al., 2008), 
developed to study how physical (e.g. ocean currents, temperature) and biological (e.g. growth or mortality) factors can affect ichthyoplankton dynamics. Ichthyop uses time series of velocity fields archived from ocean simulations of the "Model for Application at Regional Scale" (MARS 3D) developed by the Ifremer Coastal Oceanography Department (Lazure and Dumas, 2008). The MARS 3D model of the Bay of Brest (limits: $48.20^{\circ} \mathrm{N}-48.44^{\circ} \mathrm{N}$ and $4.09^{\circ} \mathrm{W}$ $-4.72^{\circ} \mathrm{W}$ ) has a horizontal resolution of $50 \mathrm{~m}$, with 20 sigma layers for vertical coordinates (equidistant layers throughout the domain that change with sea surface elevation). The model has already been validated on temperature and salinity datasets (Petton S. et al., unpublished) and previously used for trajectories of toxic algal cells released from estuarine zones (Klouch et al., 2016). The hydrodynamic model is forced by sea elevation at the boundaries obtained from an upper 2D nested model. Initial conditions of temperature and salinity were taken from a regional MARS 3D model that covers the Bay of Biscay and English Channel (PREVIMER project; Caillaud et al., 2016). Temperature and salinity are also forced at a 1-h frequency by this 3D oceanic model. Before modelling the particles in the present study, a spin-up run was done for 45 days. Freshwater inputs for main rivers (Aulne, Elorn and Mignonne) were taken from the HYDRO data bank (http://www.hydro.eaufrance.fr/). Atmospheric conditions such as atmospheric pressure, wind speed, air temperature, relative humidity and nebulosity were provided by the Arome model from Météo-France and used throughout the domain. Surface velocity fields, interpolated at $1 \mathrm{~m}$ below the sea surface elevation from the 3D MARS model, were extracted at 15 min time steps to launch Ichthyop runs. Ichthyop code was also modified to set 25 particles evenly distributed within each grid mesh of the whole hydrodynamic model inside the bay, which led to a total of $1,437,500$ passive particles for each run. Coastline behaviour was set as beaching, as the MARS 3D model is implemented with a wetting-drying numerical method in intertidal areas. To assess the dispersion of particles, the Bay of Brest was divided into five tracking zones: Elorn estuary, Daoulas bay, Aulne estuary, and the centre and south of the bay (Fig. 1). To get an overview of the dispersion of floating particles in the Bay of Brest, four release conditions were tested that differed for important hydrodynamic drivers known to be sources of MP (e.g. Li et al., 2016) and/or important in the Bay of Brest due to their characteristics: initial tide periods during the first five days of simulation (neap versus spring tides) and river inflows during the whole simulation (rise in water level, hereafter called flood water $v$ s. low water). Wind direction and intensity effects were not precisely studied in this paper as they are highly variable in the bay, but were taken into account in the simulations. Four realistic computational periods of 10 days were run, two in February and two in September 2013. Environmental conditions of these computational periods are summarized in Supplementary Table S1. For one typical situation, high tide conditions were chosen and 13 simulations made with different release times, from $6 \mathrm{~h}$ before high tide until $6 \mathrm{~h}$ after high tide, with an hourly time step in order to avoid tide bias. A 10-day simulation period was chosen as a compromise between available computer computation time (related to available memory) and reliability of modelling patterns (Caillaud et al., 2016). Horizontal particle dispersion was defined as the standard condition of the Ichthyop model, based on Peliz et al. (2007), with a dissipation rate of $1.10^{-9} \mathrm{~m}^{2} \mathrm{~s}^{-3}$. The numerical time steps of both Ichthyop and the hydrodynamic model were set at $6 \mathrm{~s}$ and trajectory output positions were recorded at hourly intervals. To obtain the tracking results for one typical situation, the ratio of the number of particles inside an area over initial number was estimated at each trajectory output time step and then averaged across the 13 simulations.

The movements of microplastics in the water column are mainly driven by their density, size and shape but can also be modified by wind-induced turbulence (Kukulka et al., 2012) and the presence of biofilms on their surface (Ballent et al., 2013; Enders et al., 2015; Kukulka et al., 2012). As the current state of knowledge does not allow the integration of complex biological processes (for instance the impacts of fouling and grazing) into the modelling of MP behaviour in the water column, the present study focused on microplastics simulated as inert particles and did not take into account their vertical motion. Limitations of the model are acknowledged in the Discussion section.

\subsection{Statistical analysis}

To test the difference in proportions of identified and nonidentified particles, the polymer type distribution and the size range (major axis) between surface water samples and sediment samples, Chi-square tests were used to check for statistical differences. The mean ( \pm standard deviation, SD) MP concentration was calculated at each station. All statistical analyses were conducted using the RStudio 0.99.491 platform (R Core Team, 2016). The significance level was set at 95\%. Maps were produced using ArcGIS (version 10.2.2) and modified using Adobe Illustrator (version 16.0.0).

\section{Results}

\subsection{Marine litter and airborne contamination}

\subsubsection{Marine litter}

Items collected in the two surveys were first described by their shape and then analysed by spectroscopy. Their distribution between categories was as follows: in surface water samples, fragments $53 \%$, fibres $25 \%$, foams $11 \%$, thin sheets $8 \%$ and pellets $3 \%$; in sediment samples, fragments $71 \%$, fibres $21 \%$, and thin sheets $8 \%$ (Supplementary Tables S3 and S4).

\subsubsection{Airborne contamination}

The fibres collected in the surface water and sediment samples were mostly of the same colour as those collected in procedural blanks. Both samples and almost all field and laboratory procedural blanks contained red, blue and black fibres ( $19 \pm 7$ fibres per blank), making firm conclusions difficult to draw. Although fibres were recorded (Supplementary Tables S5 and S6) and counted among the collected items in the present study (Supplementary Tables S3 and S4), they were excluded from the actual MP concentration calculation. This analytical restriction is discussed in the Discussion section.

\subsection{Surface water contaminated by microplastics}

\subsubsection{Microplastic composition}

In the two surveys, MP were detected at all stations except station E2 in spring 2014. Across the nine stations sampled in spring and autumn, 965 microparticles were collected (excluding fibres $)$ and $72 \%(n=691)$ were identified as microplastics, with a mean concentration of $0.24 \pm 0.35 \mathrm{MP} \mathrm{m}^{-3}$ and a mass concentration of $0.33 \pm 0.60 \mathrm{mg} \mathrm{m}^{-3}$ using Raman micro-spectroscopy. Three polymers were identified among the microplastics collected: the most abundant was polyethylene (PE), at $0.16 \pm 0.22 \mathrm{MP} \mathrm{m}^{-3}$ (67.4\%); followed by polypropylene (PP), at $0.04 \pm 0.05 \mathrm{MP} \mathrm{m} \mathrm{m}^{-3}$ (16.5\%); and polystyrene (PS), at $0.04 \pm 0.08 \mathrm{MP} \mathrm{m}^{-3}(16.1 \%)$. MP size class distribution was as follows: $5-2 \mathrm{~mm}$ diameter, $0.09 \pm 0.15 \mathrm{MP} \mathrm{m}^{-3}$ (37\%); 2-1 mm, $0.09 \pm 0.13 \mathrm{MP} \mathrm{m}^{-3}(37 \%) ; 1-0.335 \mathrm{~mm}, 0.06 \pm 0.07 \mathrm{MP} \mathrm{m}^{-3}(26 \%)$ (Supplementary Table S7). Among the remaining 274 nonidentified particles (28\%), different types of spectra were found: 
quartz (3\%); phthalocyanine blue 15 (PB15), a blue pigment usually used to colour plastics (2\%); calcium carbonate (1\%); particles whose spectra did not match any in the databases (1\%); and particles that could not be identified (no signal or a saturated signal due to fluorescence, 21\%) (Supplementary Fig. S1).

\subsubsection{Variability in microplastic concentration and distribution}

Temporal variability in the quantity of microplastics was observed between surveys in spring and autumn. In spring, samples collected from eight of the nine stations contained MP, with a total of $230 \mathrm{MP}$ items collected, corresponding to a mean MP concentration of $0.13 \pm 0.13 \mathrm{MP} \mathrm{m}^{-3}$ and a mass concentration of $0.28 \pm 0.52 \mathrm{mg} \mathrm{m}^{-3}$. In autumn, all samples contained MP, with a total of $480 \mathrm{MP}$ corresponding to a mean MP concentration of $0.35 \pm 0.46 \mathrm{MP} \mathrm{m}^{-3}\left(0.38 \pm 0.70 \mathrm{mg} \mathrm{m}^{-3}\right.$ ) (Fig. 2; Supplementary Table S7). The higher quantities of MP measured in autumn, compared to spring, were mainly observed in the area characterized by intense anthropogenic activity (military, recreational and commercial ports, stations A1-A3) (Fig. 2).

The spatial distribution of microplastics in the Bay of Brest was similar between the two surveys. The highest MP concentration was found at site M1, which is a site influenced by a mix of waters coming from the Iroise Sea and the centre of the bay $\left(0.43 \mathrm{MP} \mathrm{m}^{-3}\right.$ and $1.43 \mathrm{MP} \mathrm{m}^{-3}$ in spring and autumn, respectively) (Fig. 2; Supplementary Table S7). The lowest MP concentration was systematically found at site E2, at the mouth of the Mignonne, with no MP collected in spring and a very small concentration of $0.01 \mathrm{MP} \mathrm{m}^{-3}$ in autumn (Fig. 2; Supplementary Table S7).

Relatively low variability in MP concentration was observed among samples of surface water from stations located close to the urbanized area of Brest (A1, A2 and A3), with mean values ranging from $0.12 \pm 0.07 \mathrm{MP} \mathrm{m}^{-3}$ in spring to $0.48 \pm 0.01 \mathrm{MP} \mathrm{m}^{-3}$ in autumn. Higher variability was observed within the areas characterized by mixing waters (M1-M3) and riverine inputs (E1-E3). For instance, surface waters of the most northern sites (E1 and M1, located close to intense anthropogenic activity areas) systematically showed higher MP concentrations than those of the sites located further south (E2, E3 and M2, M3) (Fig. 2; Supplementary Table S7).

\subsection{Sediment contamination by microplastics}

\subsubsection{Microplastic composition}

Only half of the sediment samples contained MP across the two surveys. Out of the nine stations sampled during winter and autumn, 229 particles were collected (excluding fibres) and 13\% $(\mathrm{n}=30)$ were identified as MP, with a mean concentration of $0.97 \pm 2.08 \mathrm{MP} \mathrm{kg}^{-1} \mathrm{DW}$ (a mass concentration of $\left.0.11 \pm 0.16 \mathrm{mg} \mathrm{kg}^{-1} \mathrm{DW}\right)$. Three polymers were identified among the analysed microplastics. The most abundant was polyethylene (PE), at $0.51 \pm 1.23 \mathrm{MP} \mathrm{kg}^{-1} \mathrm{DW}$ (53.3\%); followed by polypropylene (PP), at $0.31 \pm 0.74 \mathrm{MP} \mathrm{kg}^{-1} \mathrm{DW}(30 \%)$; and polystyrene (PS), at $0.15 \pm 0.29 \mathrm{MP} \mathrm{kg}^{-1} \mathrm{DW}(16.7 \%)$. The MP size class distribution was as follows: no particles were found in the $5-2 \mathrm{~mm}$ size class, particles of $2-1 \mathrm{~mm}$ were found at $0.26 \pm 0.82 \mathrm{MP} \mathrm{kg} \mathrm{kW}^{-1} \mathrm{DW}(27 \%)$; $1-0.335 \mathrm{~mm}$ at $0.52 \pm 1.11 \mathrm{MP} \mathrm{kg}^{-1} \mathrm{DW}(53.5 \%)$; and $<0.335 \mathrm{~mm}$ at $0.19 \pm 0.30 \mathrm{MP} \mathrm{kg}^{-1} \mathrm{DW}$ (19.5\%). The smallest MP measured $207 \mu \mathrm{m}$ in the major axis and $153 \mu \mathrm{m}$ in the minor axis (Supplementary Table S8). Among the 199 (87\%) particles remaining that were not identified as plastic, the following different types were found:

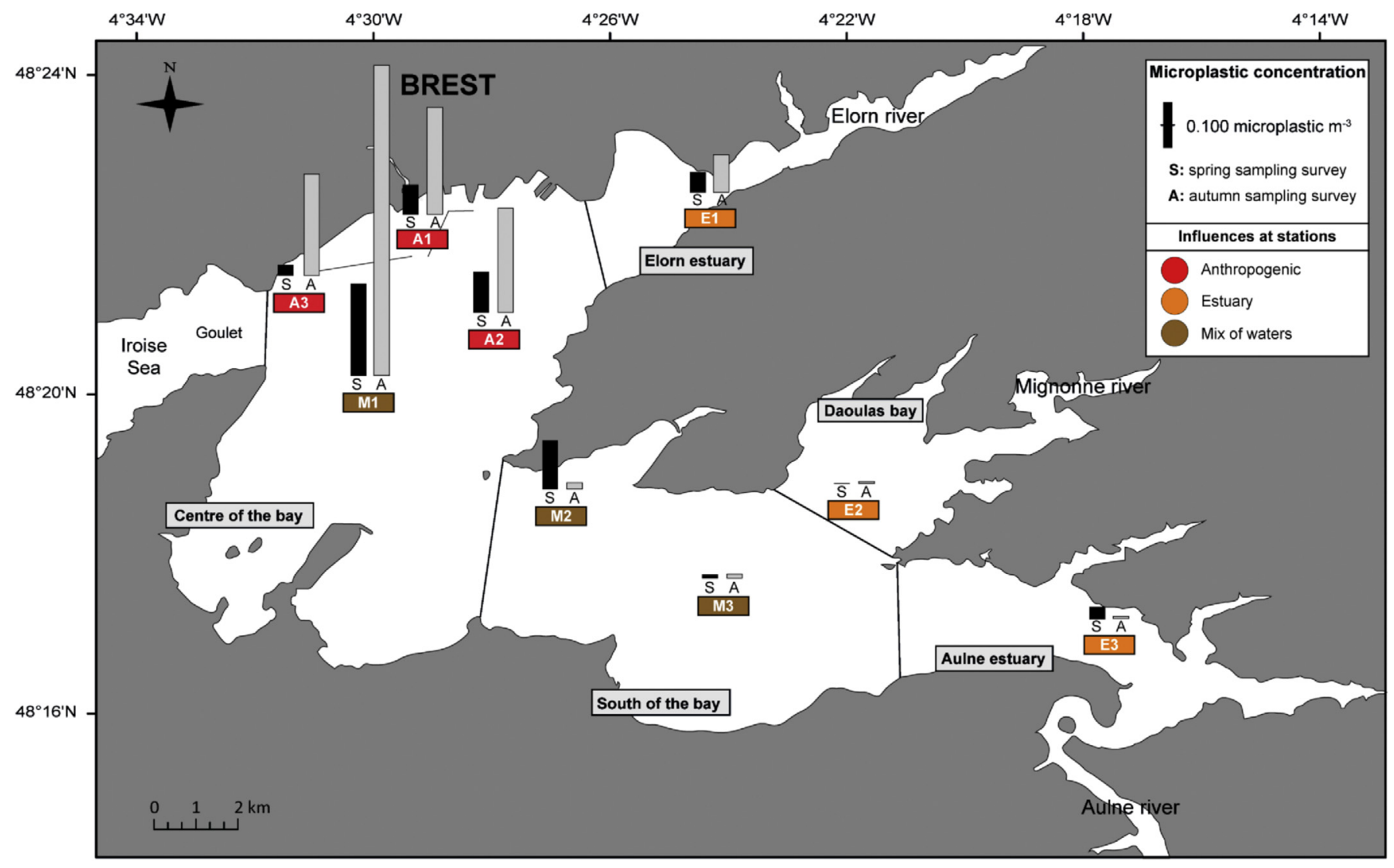

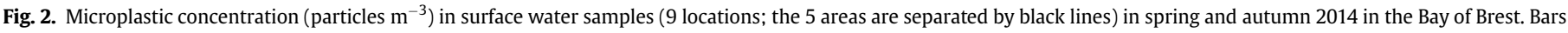
on the chart are proportional to microplastic concentration. 
calcium carbonate (15\%), quartz (10\%), PB15 (2\%), particles whose spectra did not match any in the databases (1\%) and particles that could not be identified (no signal or a saturated signal due to fluorescence, $59 \%$ ). It is noteworthy that there were significantly more particles in sediment samples whose spectra showed fluorescence or no signal than in those collected in surface water $(\mathrm{P}<0.05)$.

\subsubsection{Variability in microplastic concentration and distribution}

Spatial and temporal variability was observed in the distribution and concentration of MP in Bay of Brest sediment. In winter, five out of the nine sites contained MP. A total of 27 MP items were collected, corresponding to a mean MP concentration of $1.53 \pm 2.84 \mathrm{MP} \mathrm{kg}^{-1} \mathrm{DW}\left(0.14 \pm 0.20 \mathrm{mg} \mathrm{kg}^{-1} \mathrm{DW}\right)$. In autumn, MP were only found in samples from four sites out of the nine and a lower number of plastic particles were collected than in winter, with a total of 10 MP corresponding to a mean of $0.40 \pm 0.67 \mathrm{MP} \mathrm{kg}{ }^{-1} \mathrm{DW}\left(0.07 \pm 0.09 \mathrm{mg} \mathrm{kg}^{-1} \mathrm{DW}\right.$ ) (Fig. 3; Supplementary Table S8).

The highest MP concentration was found at station M3, which is influenced by a mix of waters from the southern part of the bay in winter ( $8.74 \mathrm{MP} \mathrm{kg}^{-1} \mathrm{DW}$ ), and at station $\mathrm{A} 3$, which is influenced by a high level of human activity (2.03 $\left.\mathrm{MP} \mathrm{kg}^{-1} \mathrm{DW}\right)$. No MP were found in samples from stations A1 to A3 (influenced by harbours and WWTP) and E3 (mouth of the Aulne river) during the winter survey, and in stations A1, A2 (harbour influence), E1, E2 (mouth of the Elorn and Mignonne rivers) and M3 (mix of waters in the area located in the southern part of the bay) during the autumn survey.

Spatial variability in the quantity of MP collected was noticed within each area, except for area A in winter where no MP were found regardless of the station. At the same time, the variability among stations sampled in mixed water areas $\left(3.26 \pm 4.75 \mathrm{MP} \mathrm{kg}^{-1}\right.$ DW) was higher than among stations located in estuary areas $\left(1.32 \pm 1.27 \mathrm{MP} \mathrm{kg}^{-1} \mathrm{DW}\right)$. In autumn, variability in the quantity of MP collected was observed in all areas of the bay: $0.68 \pm 1.17 \mathrm{MP} \mathrm{kg}{ }^{-1} \mathrm{DW}, 0.16 \pm 0.28 \mathrm{MP} \mathrm{kg}{ }^{-1} \mathrm{DW}$ and $0.37 \pm 0.39 \mathrm{MP} \mathrm{kg}^{-1} \mathrm{DW}$ for the human-influenced, estuarine and mixed water areas, respectively (Fig. 3; Supplementary Table S8).

\subsection{Hydrodynamic modelling of the Bay of Brest}

The four realistic conditions tested with initial releases (neap and spring tides, flood and low water) were chosen to be representative of the main hydrodynamic drivers in the Bay of Brest. After 10 days of simulations, the mean value of particles remaining in the Bay of Brest for the four conditions tested was $19.7 \pm 10.3 \%$, and beached particles represented $14.3 \pm 9.5 \%$ of the total number of particles set up at T0. The remaining percentage (66 $\pm 19 \%)$ comprised particles considered by the model to be expelled from the bay through the narrow strait (the Goulet, see Fig. 1) linking it to the Iroise Sea. The releases of particles in the model showed similar patterns between neap and spring tides, and between flood and low water periods (Fig. 4). Even though some variability in particle dispersion occurred within the first four days due to hydrodynamic drivers, these did not notably influence the dispersion of particles for more than 8 days. After 8 days, only a few particles remained in Daoulas bay, and Aulne and Elorn estuaries (Fig. 4). Before being flushed out, particles converged in the centre and the south of the bay while decreasing in number in the other areas (Fig. 4) during flood tide. At each tidal cycle, one-third of the total water volume is

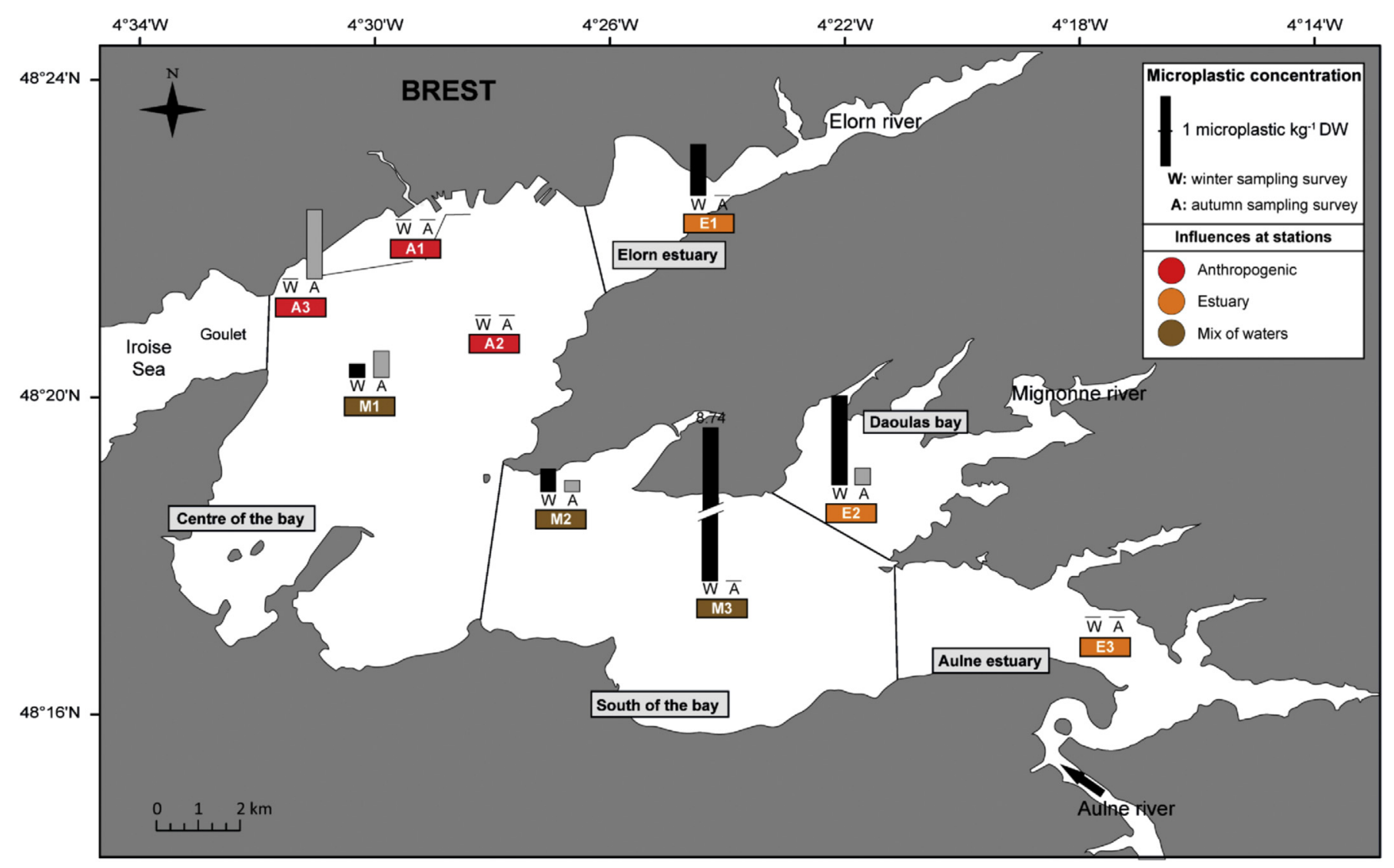

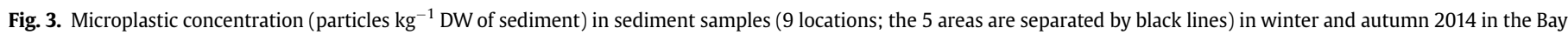
of Brest. Bars on the chart are proportional to microplastic concentration. 
Bay of Brest

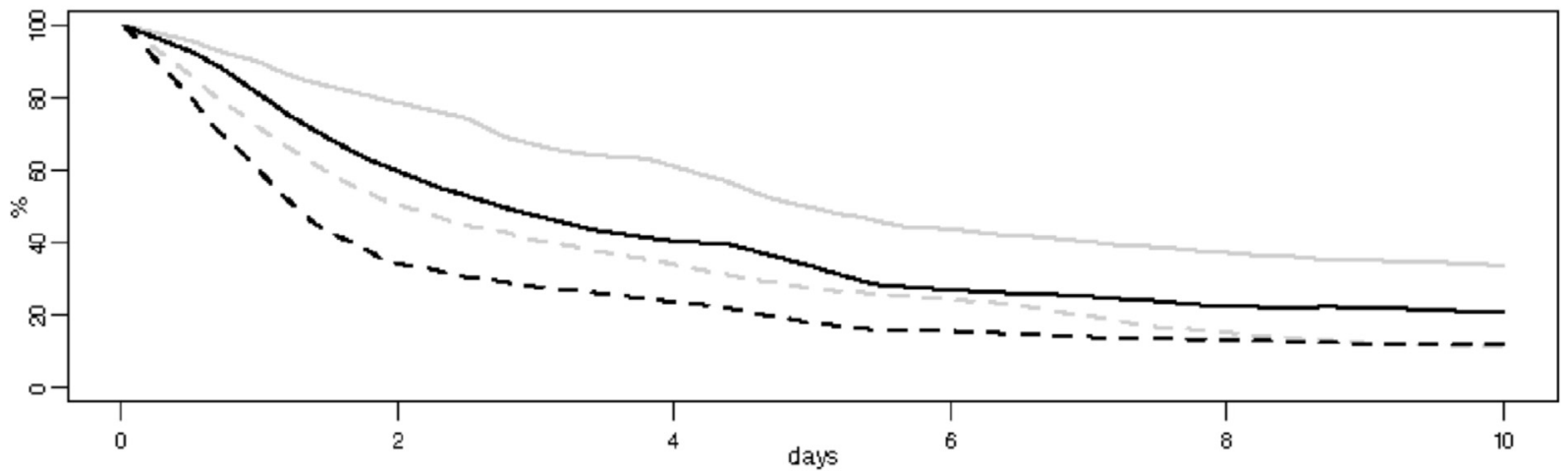

Daoulas bay
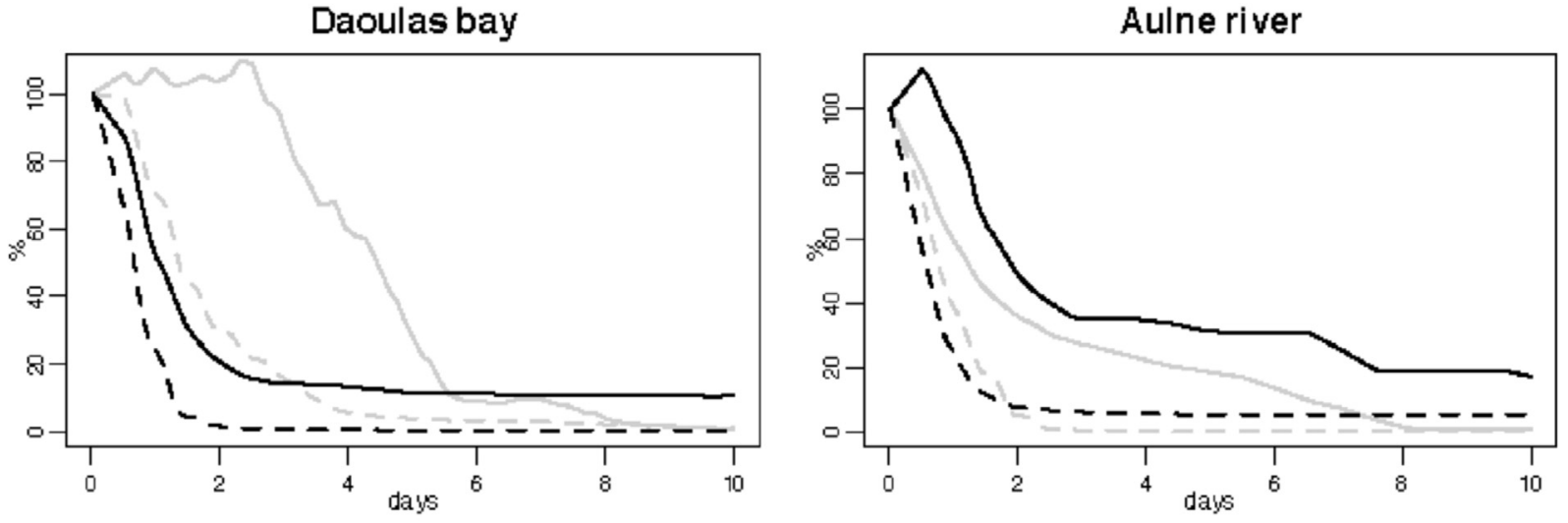

Elorn river
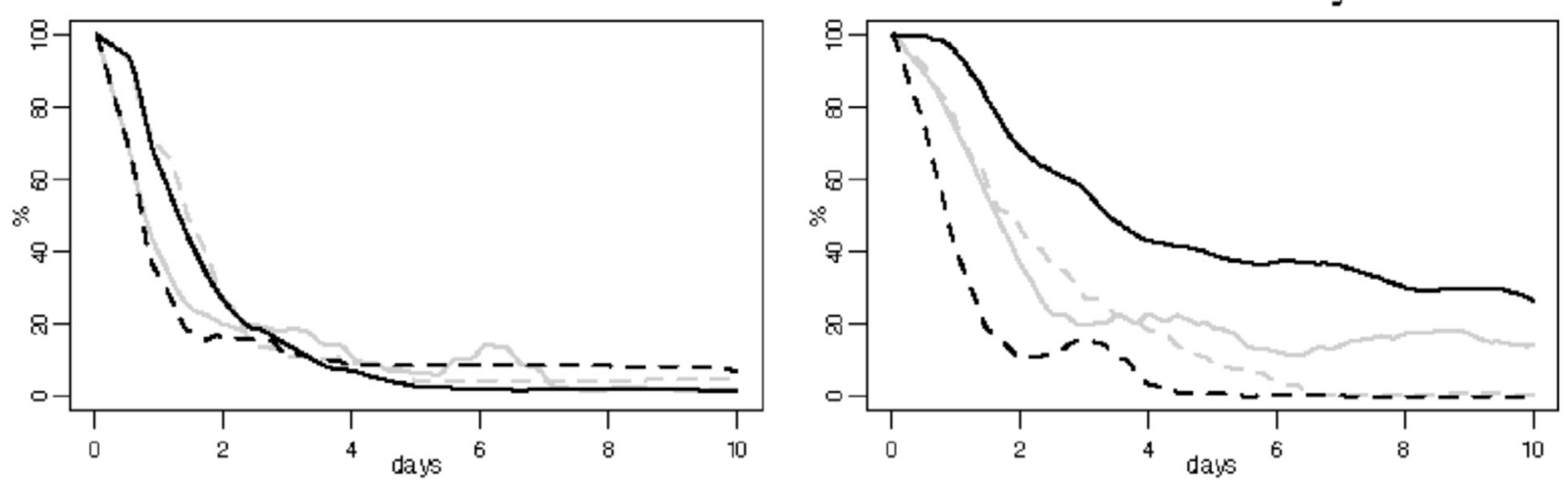

Center of the bay

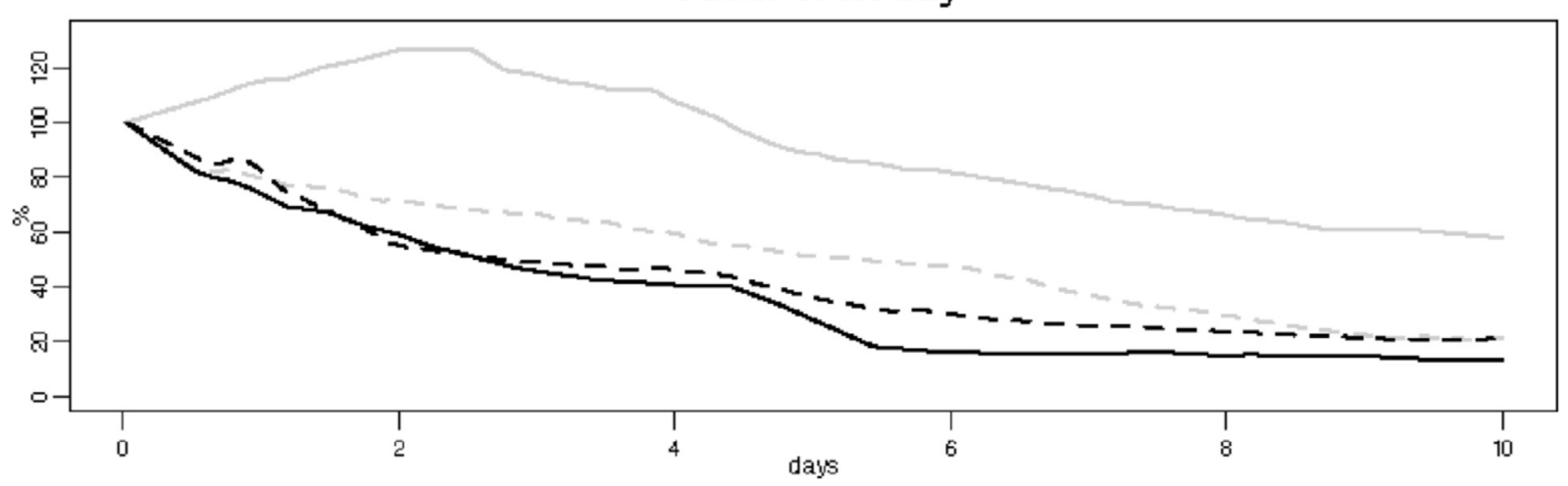

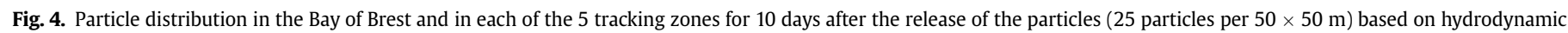

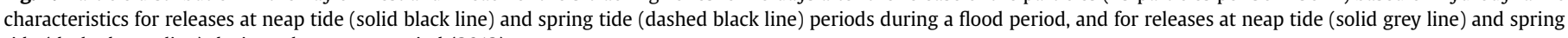
tide (dashed grey line) during a low water period (2013). 
expulsed out of the bay into the Iroise Sea (part of the Atlantic Ocean) (Troadec and Le Goff, 1997) and particles are consequently washed out of the bay. Wind might also be a determining factor for particle dispersion due to its direct impact on sea surface current. Neither can we exclude drivers like wind-driven oceanic currents that may affect dispersion of the particles in the modelled bay.

\section{Discussion}

\subsection{Microplastics in the Bay of Brest: dominance of polyethylene fragments}

Microplastics (MP) were detected throughout the Bay of Brest, both in surface water and sediment, in accordance with reports of the ubiquity of this emerging contaminant throughout the marine environment (Browne et al., 2011; Eriksen et al., 2014). The dominance of fragments in surface water and sediment samples over other types of marine debris (film, foam, pellets and fibres) suggests that the source of MP in the bay is more related to the breakdown of larger plastic debris (Andrady, 2011; Cole et al., 2011; Vianello et al., 2013) than to direct primary inputs such as those expected from wastewater treatment plants (WWTP) where textile-derived fibres are dominant (Browne et al., 2011; Murphy et al., 2016; Sutton et al., 2016). However, fragments can also include microplastics derived from personal care products because these are irregular in shape (Carr et al., 2016). Plastic polymers collected in the Bay of Brest were made of polyolefins (PE and PP) and polystyrene (PS). Polyethylene (PE) was the dominant polymer found in the Bay of Brest (53.3-67.4\%) in accordance with the scale of its global manufacture and use worldwide (Antunes et al., 2013; GESAMP, 2015; MorétFerguson et al., 2010). It represented 29.3\% of European demand for plastics in 2014 (PlasticsEurope, 2016). The dominance of PE in the bay is consistent with other environmental surveys conducted in aquatic environments (Enders et al., 2015; Isobe et al., 2014). Together with the two other polymers identified in the bay, PE, PP and PS are members of the "Big Six" (PET, HDPE, uPVC, LDPE, PP, PS), which account for $80 \%$ of plastic production in Europe (PlasticsEurope, 2016). They are commonly used for plastic products with a relatively short usage lifetime (GESAMP, 2015) and are consequently also the most commonly reported polymers in marine environments (Browne et al., 2010; Karapanagioti et al., 2011; Vianello et al., 2013).

The presence of buoyant MP (PE, PP and PS) in the sediment of the bay suggests the existence of sedimentation processes related to ageing processes that modify particle density and shape (Chae et al., 2015; Cole et al., 2011), surface biofilm development (Cózar et al., 2014) that makes MP less hydrophobic (Lobelle and Cunliffe, 2011), or their incorporation into marine aggregates that force them to sink (Long et al., 2015). Considering that none of these complex phenomena are sufficiently well understood for inclusion in modelling, the vertical behaviour of MP was not taken into account in the present work. In addition to inferences recently made with particle sizes dependent on the Reynolds number (Enders et al., 2015; Kukulka et al., 2012), future challenges include modelling the $\mathrm{z}$ dimension and, hence, inferring complex MP sedimentation.

It is noteworthy that dense MP such as PVC, PA or alkyd (Vianello et al., 2013) were not detected, despite the fact that a very dense solution $\left(1.56 \mathrm{~g} \mathrm{~cm}^{-3}\right)$ was used for their extraction and that this procedure was confirmed to be effective in a spiking experiment. However, as 59\% of the particles collected remained unidentified, it is possible that some dense MP could have been hidden in this fraction, especially if the polymers were mixed with dyes (e.g. PB 15), as this may prevent their identification (Frère et al., 2016).

\subsection{Spatial and temporal variability in the distribution of floating microplastics}

The mean MP concentration found in surface water of the Bay of Brest $\left(0.24 \pm 0.35 \mathrm{MP} \mathrm{m}^{-3}\right)$ was similar to that found in other coastal ecosystems such as the Goiania estuary in Brazil (0.26 $\mathrm{MP} \mathrm{m}^{-3}$ ) (Lima et al., 2014), the Tamar estuary in the Western English Channel (0.27 MP m${ }^{-3}$ ) (Cole et al., 2014) and the semienclosed Northwestern Mediterranean sea (values ranging from $0.15 \mathrm{MP} \mathrm{m} \mathrm{m}^{-3}$ to $0.27 \mathrm{MP} \mathrm{m}^{-3}$ depending on the distance from pollution point sources) (de Lucia et al., 2014). Proximity of urban areas and river runoff have been linked to high microplastic concentration in surface waters (Frias et al., 2014). MP spatial variability may be primarily explained by the nature and location of the pathways and their distance from anthropogenic activities (Faure et al., 2015; Sá et al., 2016; Tubau et al., 2015). Sites A1, A2 and A3 exhibited high MP concentration probably as a result of high urbanization in this area, there being two marinas (Château and Moulin Blanc), military and commercial harbours and significant effluent from the main water treatment plant of the bay (treating sewage from more than 134,377 people, and generating $25,300 \mathrm{~m}^{3}$ day $^{-1}$ of effluent). This area is also the most densely urbanized area in the bay (2815 people $\mathrm{km}^{-2}$ for a surface area of $49 \mathrm{~km}^{2}$; INSEE, 2013, compared with 210 people $\mathrm{km}^{-2}$ for a surface area of $370 \mathrm{~km}^{2}$ over the rest of the bay area; INSEE, 2013) leading to higher loads of urban runoff and direct discharges. Concerning locations at the mouths of the main rivers, higher MP loads were detected at the mouth of the most densely populated river (Site E1, Elorn river: 253 people $\mathrm{km}^{-2}$ ) compared with the other rivers (E2 Aulne river and E3 Mignonne river $<38$ people $\mathrm{km}^{-2}$ ).

Hydrodynamic factors influence MP distribution in coastal areas (Rocha-Santos and Duarte, 2014), especially as a result of upper sea surface circulation. For instance, the highest MP concentrations in the Bay of Brest were found in its centre, which is likely related to the formation of a transitional convergence zone, as suggested by the outputs of the particle dispersal model, regardless of the hydrodynamic conditions tested (i.e. river outflows and tide coefficient) and under wind variability (direction, intensity). This was noticed in prior hydrodynamic studies, which showed the formation of an anticyclonic gyre in the centre of the bay at flood tide, while at ebb tide the entire tidal current left the bay through the Goulet (Monbet and Bassoulet, 1989; Salomon and Breton, 1991; Guérin, 2004; Beudin et al., 2013). Indeed, the particle dispersal model also showed that more than $60 \%$ of the particles were expelled from the bay after 10 days. All these findings suggest that passive particle trajectories converge towards the centre of the bay, transitory under the effect of the tide, before mostly being expelled from the bay. This is in agreement with our observations: the highest MP concentration was found at site M1, which is influenced by a mix of waters coming from the Iroise Sea and the centre of the bay. These results suggest that the Bay of Brest is probably a dispersive coastal system with no permanent sea surface accumulation structures able to concentrate plastic particles, as observed in modelling studies conducted in the Adriatic and Mediterranean seas (Liubartseva et al., 2016; Mansui et al., 2015). It is therefore interesting to observe and model average MP residence time in the Bay of Brest, although such results must be considered with caution due to the limits of the model. Such limitations include i) the open boundary avoiding the possible entry of oceanic particles or re-entry of MP expelled from the bay, although the frontier of the model includes an oceanic zone (part of the Iroise sea) corresponding to the tidal prism of the bay (Salomon and Breton, 1991), which allows trajectories of the particles that exited via the Goulet to re-enter. Such re-entry appeared very low compared with particle outflow over the modelled timescale. Other 
points about the model that should be borne in mind are: ii) the beaching behaviour; iii) the vertical behaviour of MP, which is very complex and for which input data are required before being realistically modelled; and iv) the sources that need observations/ quantification for further runs. Indeed, it would be of great interest to further refine details on outputs and sources. Klouch et al. (2016) studied the trajectories of Alexandrium minutum cells in the surface water of the Bay of Brest, considering only the mouth of the main rivers where the blooms of $A$. minutum occur. Considering estuaries as starting points for $A$. minutum cell release, the retention of the particles appeared higher, from 56 to $81 \%$, compared to our study. In future work, fine spatial and temporal sampling of MP sources plus 3D dimensional modelling (of river mouths, beaches, wastewater treatment plants, etc.) would allow a better understanding of MP behaviour in a shallow, semi-enclosed, and urbanized marine ecosystem such as the Bay of Brest.

The variability of MP distribution observed between spring and autumn may be due to small scale water movements, which are known to be highly time dependent due to quickly changing wind and sea conditions (GESAMP, 2015). While wind-induced mixing is also known to affect the vertical distribution of MP in the water column (Reisser et al., 2015), this may not have played a major role in the differences in MP concentrations observed between the two surveys, as the wind conditions during the manta sampling were below the wind speed threshold known to induce this phenomenon $\left(<5 \mathrm{~m} \mathrm{~s}^{-1}\right)$ (Lattin et al., 2004; Reisser et al., 2015). Wind forcing conditions should be further tested using time series observations and modelling, keeping in mind that no significant oceanic circulation related to the prevailing winds is expected in the bay because there is only a very small distance over which the wind can blow in the same direction before reaching the shore (i.e. a very small fetch).

To further explore the spatial and temporal variability in MP concentrations at the sea surface, more data are required and vertical motion must be taken into account in modelling work. Although the MARS 3D hydrodynamic model and Ichthyop dispersal model combined are able to integrate the vertical dimension for particles, taking into account extrinsic processes such as wind-induced turbulence, further studies are needed to integrate complex biological processes (e.g. fouling and grazing, with their associated rising and falling velocities) that may impact the vertical distribution of MP (Besseling et al., 2017).

\subsection{Sediments have a relatively low microplastic content}

Overall, the mean MP concentration found in the sediment of the Bay of Brest $\left(0.97 \pm 2.08 \mathrm{MP} \mathrm{kg}^{-1} \mathrm{DW}\right)$ was below that reported in other areas, such as the United Kingdom (up to 31 particles $\mathrm{kg}^{-1}$ estuarine sediment) (Thompson et al., 2004), along the Belgium coast $\left(97.2 \pm 18.6\right.$ particles $\left.\mathrm{kg}^{-1} \mathrm{DW}\right)$ (Claessens et al., 2011) and in the Venice Lagoon in Italy $\left(672-2175\right.$ particles $\mathrm{kg}^{-1} \mathrm{DW}$ ) (Vianello et al., 2013). However, it is worth mentioning that the high proportion of unidentified particles (59\%) and the fact that fibres were not included in the present study may lead to lower concentration values than those reported in prior studies, notably some that have shown a large amount of fibres in sediment samples (e.g. Claessens et al., 2011). However, it should be mentioned that other studies have shown a limited proportion of fibres in the MP found in sediment: for example, fibres represented only $10 \%$ of polymers in the sediments of Venice Lagoon (Vianello et al., 2013). In our study, the exclusion of non-identified fibres was considered to be a more rigorous approach, which would avoid overestimating the MP concentration in the Bay of Brest. It was justified by i) the nonnegligible quantities of fibres found in all of our procedural blanks, ii) the impossibility of discriminating fibres optically or to identify their molecular composition with the Raman microspectroscopy method used here (data not shown; Dris, 2016), and iii) the high proportion of non-plastic natural fibres (cellulose, natural cellulose-based polymers like cellophane or protein-based polymers) reported in environmental samples when spectroscopic methods are employed to verify the nature of the collected fibres (Collard et al., 2015; Rémy et al., 2015; Wesch et al., 2016).

If this low amount of MP in the sediment is confirmed, it could be explained by a reduced time for sedimentation and the intense flush out of the bay compared with other estuaries (Deloffre et al., 2007; Gouleau et al., 2000). Indeed, Ehrhold et al. (2016) showed that the rate of sedimentation is negligible in the centre of the bay and increases slightly close to river mouths (up to $0.5 \mathrm{~cm} \mathrm{yr}^{-1}$ ). The shallowness of the Bay of Brest enhances vertical water mixing and sediment resuspension (Pommepuy, 1977) which may have further prevented sedimentation and accumulation of MP in the sediment; all sampled stations have a depth below $20 \mathrm{~m}$ (mean depth: $12 \pm 5 \mathrm{~m}$ ). Finally, even though the highest MP concentrations were found in sediment close to WWTP (site A3) and to active aquaculture areas (mainly oyster and mussel farming activities) in estuarine areas (sites M3 and E2), both known to be important sources of MP in the marine environment (Murphy et al., 2016; Sá et al., 2016; Unger and Harrison, 2016), no consistent pattern was revealed in sediment between sampling periods, and no permanent MP accumulation zone was found in the sediment of the Bay of Brest.

One limitation of this study is the high proportion of unidentified particles. Pre-treatment of sediment samples, for example to remove organic matter, could reduce the proportion of unidentified particles, as suggested by Imhof et al. (2016). If developed successfully, such new improved methods should then be systematically applied in further studies to assess spatial and temporal variability of MP in the sediment of coastal environments.

\section{Conclusion}

The present work demonstrated the dominance of polyethylene, polypropylene and polystyrene fragments in both the surface water and sediment of the Bay of Brest. The presence of relatively buoyant MP in the sediment suggests the existence of physical and/or biological processes forcing buoyant MP to sink to the bottom of the bay. Temporal and spatial heterogeneities were observed in the abundance and distribution of microplastics, emphasizing the need for fine-scale temporal sampling to encompass the whole extent of MP contamination in such an active coastal ecosystem. Finally, data collection in freshwater inputs (rivers and water treatment plants) is needed to better inform the modelling of the MP source path and fate in coastal ecosystems.

\section{Acknowledgements}

This work was supported by the Unique Inter-ministerial Fund (FUI) and the local communities (CR Bretagne, CR PACA, CD29, CATPM and Brest Métropole) as part of the MICROPLASTIC2 project and by the ANR CESA (ANR-15-CE34-0006-02, NANOPLASTICS project). We acknowledge O. Gauthier, M. Cachera, G. Schaal, G. Grégoire, P. Le Hir and A.L. Cassone for helpful discussions and technical assistance. We thank A. Volety, R. Whittington and Helen McCombie for their help in editing the English. L. Frère was funded by a french doctoral research grant (DDP150097 ARED-FRERE) from Brest Métropole (50\%) and University of Brest (50\%).

\section{Appendix A. Supplementary data}

Supplementary data related to this article can be found at http:// 
dx.doi.org/10.1016/j.envpol.2017.03.023.

\section{References}

Andrady, A.L., 2011. Microplastics in the marine environment. Mar. Pollut. Bull. 62, 1596-1605. http://dx.doi.org/10.1016/j.marpolbul.2011.05.030.

Antunes, J.C., Frias, J.G.L., Micaelo, A.C., Sobral, P., 2013. Resin pellets from beaches of the Portuguese coast and adsorbed persistent organic pollutants. Press. Stress. Shock. Trends Estuar. Ecosyst. 130, 62-69. http://dx.doi.org/10.1016/ j.ecss.2013.06.016.

Arthur, C., Baker, J., Bamford, H., 2009. Proceedings of the International Research Workshop on the Occurrence, Effects, and Fate of Microplastic Marine Debris, 530pp.

Ashton, K., Holmes, L., Turner, A., 2010. Association of metals with plastic production pellets in the marine environment. Mar. Pollut. Bull. 60, 2050-2055. http:// dx.doi.org/10.1016/j.marpolbul.2010.07.014.

Auffret, G.A., 1983. Dynamique sédimentaire de la marge continentale celtiqueEvolution Cénozoïque-Spécificité du Pleistocène supérieur et de l'Holocène. Université de Bordeaux I, Bordeaux, p. 355.

Avio, C.G., Gorbi, S., Milan, M., Benedetti, M., Fattorini, D., d'Errico, G., Pauletto, M., Bargelloni, L., Regoli, F., 2015. Pollutants bioavailability and toxicological risk from microplastics to marine mussels. Environ. Pollut. 198, 211-222. http:// dx.doi.org/10.1016/j.envpol.2014.12.021.

Ballent, A., Pando, S., Purser, A., Juliano, M.F., Thomsen, L., 2013. Modelled transport of benthic marine microplastic pollution in the Nazare Canyon. Biogeosciences 10, 7957-7970. http://dx.doi.org/10.5194/bg-10-7957-2013.

Barnes, D.K.A., Galgani, F., Thompson, R.C., Barlaz, M., 2009. Accumulation and fragmentation of plastic debris in global environments. Philos. Trans. R. Soc. BBiol. Sci. 364, 1985-1998. http://dx.doi.org/10.1098/rstb.2008.0205.

Besseling, E., Quik, J.T.K., Sun, M., Koelmans, A.A., 2017. Fate of nano- and microplastic in freshwater systems: a modeling study. Environ. Pollut. 220, 540-548. http://dx.doi.org/10.1016/j.envpol.2016.10.001.

Beudin, A., Chapalain, G., Guillou, N., 2013. Suspended sediment modelling in the bay of brest impacted by the slipper limpet Crepidula Fornicata. Coast. Dyn. 193-202.

Browne, M.A., Crump, P., Niven, S.J., Teuten, E., Tonkin, A., Galloway, T., Thompson, R., 2011. Accumulation of microplastic on shorelines woldwide: sources and sinks. Environ. Sci. Technol. 45, 9175-9179. http://dx.doi.org/ 10.1021/es201811s.

Browne, M.A., Galloway, T., Thompson, R., 2007. Microplastic-an emerging contaminant of potential concern? Integr. Environ. Assess. Manag. 3, 559-561. http://dx.doi.org/10.1002/ieam.5630030412.

Browne, M.A., Galloway, T.S., Thompson, R.C., 2010. Spatial patterns of plastic debris along estuarine shorelines. Environ. Sci. Technol. 44, 3404-3409. http:// dx.doi.org/10.1021/es903784e.

Caillaud, M., Petton, S., Dumas, F., Rochette, S., Vasquez, M., 2016. Hydrodynamic Hindcast at 500m Resolution with MARS3D-AGRIF Model - Channel-Biscay Zone. IFREMER. http://doi.org/10.12770/3edee80f-5a3e-42f4-9427-9684073 C87f5.

Carr, S.A., Liu, J., Tesoro, A.G., 2016. Transport and fate of microplastic particles in wastewater treatment plants. Water Res. 91, 174-182. http://dx.doi.org/10.1016/ j.watres.2016.01.002.

Chae, D.-H., Kim, I.-S., Kim, S.-K., Song, Y.K., Shim, W.J., 2015. Abundance and distribution characteristics of microplastics in surface seawaters of the Incheon/ Kyeonggi coastal region. Arch. Environ. Contam. Toxicol. 69, 269-278. http:// dx.doi.org/10.1007/s00244-015-0173-4.

Claessens, M., Meester, S.D., Landuyt, L.V., Clerck, K.D., Janssen, C.R., 2011. Occurrence and distribution of microplastics in marine sediments along the Belgian coast. Mar. Pollut. Bull. 62, 2199-2204. http://dx.doi.org/10.1016/ j.marpolbul.2011.06.030.

Cole, M., Lindeque, P., Halsband, C., Galloway, T.S., 2011. Microplastics as contaminants in the marine environment: a review. Mar. Pollut. Bull. 62, 2588-2597. http://dx.doi.org/10.1016/j.marpolbul.2011.09.025.

Cole, M., Webb, H., Lindeque, P.K., Fileman, E.S., Halsband, C., Galloway, T.S., 2014. Isolation of microplastics in biota-rich seawater samples and marine organisms. Sci. Rep. 4 http://dx.doi.org/10.1038/srep04528.

Collard, F., Gilbert, B., Eppe, G., Parmentier, E., Das, K., 2015. Detection of anthropogenic particles in fish stomachs: an isolation method adapted to identification by Raman spectroscopy. Arch. Environ. Contam. Toxicol. 1-9. http:// dx.doi.org/10.1007/s00244-015-0221-0.

Collignon, A., Hecq, J.-H., Glagani, F., Voisin, P., Collard, F., Goffart, A., 2012. Neustonic microplastic and zooplankton in the North western Mediterranean sea. Mar. Pollut. Bull. 64, 861-864. http://dx.doi.org/10.1016/j.marpolbul.2012. 01.011.

Cózar, A., Echevarría, F., González-Gordillo, J.I., Irigoien, X., Úbeda, B., HernándezLeón, S., Palma, Á.T., Navarro, S., García-de-Lomas, J., Ruiz, A., Fernández-dePuelles, M.L., Duarte, C.M., 2014. Plastic debris in the open ocean. Proc. Natl. Acad. Sci. 201314705. http://dx.doi.org/10.1073/pnas.1314705111.

de Lucia, G.A., Caliani, I., Marra, S., Camedda, A., Coppa, S., Alcaro, L., Campani, T., Giannetti, M., Coppola, D., Cicero, A.M., Panti, C., Baini, M., Guerranti, C., Marsili, L., Massaro, G., Fossi, M.C., Matiddi, M., 2014. Amount and distribution of neustonic micro-plastic off the western Sardinian coast (Central-Western Mediterranean Sea). Mar. Environ. Res., Large Mar. Vertebr. as Sentin. GES Eur. MSFD 100, 10-16. http://dx.doi.org/10.1016/j.marenvres.2014.03.017.
Deloffre, J., Verney, R., Lafite, R., Lesueur, P., Lesourd, S., Cundy, A., 2007. Sedimentation on intertidal mudflats in the lower part of macrotidal estuaries: sedimentation rhythms and their preservation. Mar. Geol. 241, 19-32. http:// dx.doi.org/10.1016/j.margeo.2007.02.011.

Devriese, L.I., van der Meulen, M.D., Maes, T., Bekaert, K., Paul-Pont, I., Frère, L., Robbens, J., Vethaak, A.D., 2015. Microplastic contamination in brown shrimp (Crangon crangon, Linnaeus 1758) from coastal waters of the Southern North Sea and Channel area. Mar. Pollut. Bull. 98, 179-187. http://dx.doi.org/10.1016/ j.marpolbul.2015.06.051.

Dris, R., 2016. First Assessment of Sources and Fate of Macro- and Micro- Plastics in Urban Hydrosystems: Case of Paris Megacity. PhD thesis. Université Paris Est, p. 248.

Dubaish, F., Liebezeit, G., 2013. Suspended microplastics and black Carbon particles in the jade system, southern North Sea. Water. Air. Soil Pollut. 224, 1352. http:// dx.doi.org/10.1007/s11270-012-1352-9.

Enders, K., Lenz, R., Stedmon, C.A., Nielsen, T.G., 2015. Abundance, size and polymer composition of marine microplastics $\geq 10 \mu \mathrm{m}$ in the Atlantic Ocean and their modelled vertical distribution. Mar. Pollut. Bull. 100, 70-81. http://dx.doi.org/ 10.1016/j.marpolbul.2015.09.027.

Eriksen, M., Lebreton, L.C.M., Carson, H.S., Thiel, M., Moore, C.J., Borerro, J.C., Galgani, F., Ryan, P.G., Reisser, J., 2014. Plastic pollution in the World's oceans: more than 5 trillion plastic pieces weighing over 250,000 tons afloat at sea PLoS One 9, e111913. http://dx.doi.org/10.1371/journal.pone.0111913.

Eriksen, M., Maximenko, N., Thiel, M., Cummins, A., Lattin, G., Wilson, S., Hafner, J. Zellers, A., Rifman, S., 2013. Plastic pollution in the South Pacific subtropical gyre. Mar. Pollut. Bull. 68, 71-76. http://dx.doi.org/10.1016/j.marpolbul. 2012.12.021.

Ehrhold A., Gregoire G., Schmidt S., Jouet G., Le Roy P., 2016. Present-day sedimentation rates in the bay of Brest (NW France) and its evolution since the last millenaries. XV International Symposium on Oceanography of the Bay of Biscay (ISOBAY 15), Juin, Bilbao.

Faure, F., Demars, C., Wieser, O., Kunz, M., de Alencastro, L.F., 2015. Plastic pollution in Swiss surface waters: nature and concentrations, interaction with pollutants. Environ. Chem. 12, 582-591. http://dx.doi.org/10.1071/EN14218.

Fendall, L.S., Sewell, M.A., 2009. Contributing to marine pollution by washing your face: microplastics in facial cleansers. Mar. Pollut. Bull. 58, 1225-1228. http:// dx.doi.org/10.1016/j.marpolbul.2009.04.025.

Fossi, M.C., Coppola, D., Baini, M., Giannetti, M., Guerranti, C., Marsili, L., Panti, C., de Sabata, E., Clo, S., 2014. Large filter feeding marine organisms as indicators of microplastic in the pelagic environment: the case studies of the Mediterranean basking shark (Cetorhinus maximus) and fin whale (Balaenoptera physalus). Mar. Environ. Res. 100, 17-24. http://dx.doi.org/10.1016/j.marenvres. 2014.02.002.

Fossi, M.C., Panti, C., Guerranti, C., Coppola, D., Giannetti, M., Marsili, L., Minutoli, R., 2012. Are baleen whales exposed to the threat of microplastics? A case study of the Mediterranean fin whale (Balaenoptera physalus). Mar. Pollut. Bull. 64, 2374-2379. http://dx.doi.org/10.1016/j.marpolbul.2012.08.013.

Frère, L., Paul-Pont, I., Moreau, J., Soudant, P., Lambert, C., Huvet, A., Rinnert, E., 2016 A semi-automated Raman micro-spectroscopy method for morphological and chemical characterizations of microplastic litter. Mar. Pollut. Bull. 113, 461-468. http://dx.doi.org/10.1016/j.marpolbul.2016.10.051.

Frias, J.P.G.L., Otero, V., Sobral, P., 2014. Evidence of microplastics in samples of zooplankton from Portuguese coastal waters. Mar. Environ. Res. 95, 89-95. http://dx.doi.org/10.1016/j.marenvres.2014.01.001.

Galgani, F., Claro, F., Depledge, M., Fossi, C., 2014. Monitoring the impact of litter in large vertebrates in the Mediterranean sea within the european marine Strategy Framework directive (MSFD): Constraints, specificities and recommendations. Mar. Environ. Res. http://dx.doi.org/10.1016/j.marenvres.2014.02.003.

GESAMP, 2015. Microplastics in the Ocean [WWW Document]. URL. http://www. gesamp.org/data/gesamp/files/media/Publications/WG_40_Brochure_ Microplastic_in_the_ocean/gallery_2191/object_2404_large.pdf (Accessed 16 February 2016)

Goldstein, M.C., Carson, H.S., Eriksen, M., 2014. Relationship of diversity and habitat area in North Pacific plastic-associated rafting communities. Mar. Biol. 161, 1441-1453. http://dx.doi.org/10.1007/s00227-014-2432-8.

Gouleau, D., Jouanneau, J.M., Weber, O., Sauriau, P.G., 2000. Short- and long-term sedimentation on Montportail-brouage intertidal mudflat, Marennes-Oléron bay (France). Cont. Shelf Res. 20, 1513-1530. http://dx.doi.org/10.1016/S02784343(00)00035-2.

Guérin, L., 2004. La crépidule en rade de Brest: un modèle biologique d'espèce introduite proliférante en réponse aux fluctuations de l'environnement. Thèse de Doctorat. Université de Bretagne occidentale, Brest, p. 323.

Hidalgo-Ruz, V., Gutow, L., Thompson, R.C., Thiel, M., 2012. Microplastics in the marine environment: a review of the methods used for identification and quantification. Environ. Sci. Technol. 46, 3060-3075. http://dx.doi.org/10.1021 es2031505.

Institut National de la Statistique et des Etudes Economiques (INSEE), 2013: https:// www.insee.fr/fr/statistiques/1405599?geo=EPCI-242900314

Isobe, A., Kubo, K., Tamura, Y., Kako, S., Nakashima, E., Fujii, N., 2014. Selective transport of microplastics and mesoplastics by drifting in coastal waters. Mar Pollut. Bull. http://dx.doi.org/10.1016/j.marpolbul.2014.09.041.

Ivar do Sul, J.A., Costa, M.F., Barletta, M., Cysneiros, F.J.A., 2013. Pelagic microplastics around an archipelago of the Equatorial Atlantic. Mar. Pollut. Bull. 75, 305-309. http://dx.doi.org/10.1016/j.marpolbul.2013.07.040.

Imhof, H.K., Laforsch, C., Wiesheu, A.C., Schmid, J., Anger, P.M., Niessner, R., 
Ivleva, N.P., 2016. Pigments and plastic in limnetic ecosystems: a qualitative and quantitative study on microparticles of different size classes. Water Res. 98, 64-74. http://dx.doi.org/10.1016/j.watres.2016.03.015.

Jambeck, J.R., Geyer, R., Wilcox, C., Siegler, T.R., Perryman, M., Andrady, A. Narayan, R., Law, K.L., 2015. Plastic waste inputs from land into the ocean. Science 347, 768-771. http://dx.doi.org/10.1126/science.1260352.

Karapanagioti, H.K., Endo, S., Ogata, Y., Takada, H., 2011. Diffuse pollution by persistent organic pollutants as measured in plastic pellets sampled from various beaches in Greece. Mar. Pollut. Bull. 62, 312-317. http://dx.doi.org/ 10.1016/j.marpolbul.2010.10.009.

Klouch, Z.K., Caradec, F., Plus, M., Hernández-Fariñas, T., Pineau-Guillou, L., Chapelle, A., Schmitt, S., Quéré, J., Guillou, L., Siano, R., 2016. Heterogeneous distribution in sediments and dispersal in waters of Alexandrium minutum in a semi-enclosed coastal ecosystem. Harmful Algae 60, 81-91. http://dx.doi.org/ 10.1016/j.hal.2016.11.001.

Koelmans, A.A., Bakir, A., Burton, G.A., Janssen, C.R., 2016. Microplastic as a vector for chemicals in the aquatic environment: critical review and model-supported reinterpretation of empirical studies. Environ. Sci. Technol. 50, 3315-3326. http://dx.doi.org/10.1021/acs.est.5b06069.

Kukulka, T., Proskurowski, G., Morét-Ferguson, S., Meyer, D.W., Law, K.L., 2012. The effect of wind mixing on the vertical distribution of buoyant plastic debris. Geophys. Res. Lett. 39 (7).

Lattin, G.L., Moore, C.J., Zellers, A.F., Moore, S.L., Weisberg, S.B., 2004. A comparison of neustonic plastic and zooplankton at different depths near the southern California shore. Mar. Pollut. Bull. 49, 291-294. http://dx.doi.org/10.1016/ j.marpolbul.2004.01.020.

Lazure, P., Dumas, F., 2008. An external-internal mode coupling for a 3D hydrodynamical model for applications at regional scale (MARS).

Law, K.L., Morét-Ferguson, S., Maximenko, N.A., Proskurowski, G., Peacock, E.E., Hafner, J., Reddy, C.M., 2010. Plastic accumulation in the north atlantic subtropical gyre. Science 329, 1185-1188. http://dx.doi.org/10.1126/science. 1192321.

Le Pape, O., Del Amo, Y., Menesguen, A., Aminot, A., Quequiner, B., Treguer, P., 1996. Resistance of a coastal ecosystem to increasing eutrophic conditions: the Bay of Brest (France), a semi-enclosed zone of Western Europe. Cont. Shelf Res. 16, 1885-1907. http://dx.doi.org/10.1016/0278-4343(95)00068-2.

Lett, C., Verley, P., Mullon, C., Parada, C., Brochier, T., Penven, P., Blanke, B., 2008. A Lagrangian tool for modelling ichthyoplankton dynamics. Environ. Model. Softw. 23, 1210-1214. http://dx.doi.org/10.1016/j.envsoft.2008.02.005.

Li, W.C., Tse, H.F., Fok, L., 2016. Plastic waste in the marine environment: a review of sources, occurrence and effects. Sci. Total Environ. 566-567, 333-349. http:/ dx.doi.org/10.1016/j.scitotenv.2016.05.084.

Lima, A.R.A., Costa, M.F., Barletta, M., 2014. Distribution patterns of microplastics within the plankton of a tropical estuary. Environ. Res. 132, 146-155. http:// dx.doi.org/10.1016/j.envres.2014.03.031.

Liubartseva, S., Coppini, G., Lecci, R., Creti, S., 2016. Regional approach to modeling the transport of floating plastic debris in the Adriatic Sea. Mar. Pollut. Bull. 103 115-127. http://dx.doi.org/10.1016/j.marpolbul.2015.12.031.

Lobelle, D., Cunliffe, M., 2011. Early microbial biofilm formation on marine plastic debris. Mar. Pollut. Bull. 62, 197-200. http://dx.doi.org/10.1016/j.marpolbul. 2010.10.013.

Long, M., Moriceau, B., Gallinari, M., Lambert, C., Huvet, A., Raffray, J., Soudant, P. 2015. Interactions between microplastics and phytoplankton aggregates: impact on their respective fates. Mar. Chem., Part. Aquat. Environ. Invis. Exopolymers Sink. Aggregates 175, 39-46. http://dx.doi.org/10.1016/j.marchem. 2015.04.003.

Lusher, A., 2015. Microplastics in the marine environment: distribution, interactions and effects. In: Bergmann, M., Gutow, L., Klages, M. (Eds.), Marine Anthropogenic Litter. Springer International Publishing, pp. 245-307.

Lusher, A.L., McHugh, M., Thompson, R.C., 2013. Occurrence of microplastics in the gastrointestinal tract of pelagic and demersal fish from the English Channel. Mar. Pollut. Bull. 67, 94-99. http://dx.doi.org/10.1016/j.marpolbul.2012.11.028.

Lusher, A.L., Tirelli, V., O'Connor, I., Officer, R., 2015. Microplastics in Arctic pola waters: the first reported values of particles in surface and sub-surface samples. Sci. Rep. 5, 14947. http://dx.doi.org/10.1038/srep14947.

Mansui, J., Molcard, A., Ourmières, Y., 2015. Modelling the transport and accumulation of floating marine debris in the Mediterranean basin. Mar. Pollut. Bull. 91 249-257. http://dx.doi.org/10.1016/j.marpolbul.2014.11.037.

Monbet, Y., Bassoulet, P. (1989). Bilan des connaissances océanographiques en rade de Brest. Rapport CEA/IPSN, code.

Moore, C.J., Moore, S.L., Leecaster, M.K., Weisberg, S.B., 2001. A comparison of plastic and plankton in the north Pacific central gyre. Mar. Pollut. Bull. 42, 1297-1300. http://dx.doi.org/10.1016/S0025-326X(01)00114-X.

Morét-Ferguson, S., Law, K.L., Proskurowski, G., Murphy, E.K., Peacock, E.E., Reddy, C.M., 2010. The size, mass, and composition of plastic debris in the western North Atlantic Ocean. Mar. Pollut. Bull. 60, 1873-1878. http:/ dx.doi.org/10.1016/j.marpolbul.2010.07.020.

Murphy, F., Ewins, C., Carbonnier, F., Quinn, B., 2016. Wastewater treatment works (WwTW) as a source of microplastics in the aquatic environment. Environ. Sci. Technol. 50, 5800-5808. http://dx.doi.org/10.1021/acs.est.5b05416.

Murray, F., Cowie, P.R., 2011. Plastic contamination in the decapod crustacean Nephrops norvegicus (Linnaeus, 1758). Mar. Pollut. Bull. 62, 1207-1217. http:/ dx.doi.org/10.1016/j.marpolbul.2011.03.032.

Ng, K.L., Obbard, J.P., 2006. Prevalence of microplastics in Singapore's coastal marine environment. Mar. Pollut. Bull. 52, 761-767. http://dx.doi.org/10.1016 j.marpolbul.2005.11.017.

Ogata, Y., Takada, H., Mizukawa, K., Hirai, H., Iwasa, S., Endo, S., Mato, Y., Saha, M. Okuda, K., Nakashima, A., Murakami, M., Zurcher, N., Booyatumanondo, R., Zakaria, M.P., Dung, L.Q., Gordon, M., Miguez, C., Suzuki, S., Moore, C., Karapanagioti, H.K., Weerts, S., McClurg, T., Burres, E., Smith, W. Velkenburg, M.V., Lang, J.S., Lang, R.C., Laursen, D., Danner, B., Stewardson, N., Thompson, R.C., 2009. International Pellet Watch: global monitoring of persistent organic pollutants (POPs) in coastal waters. 1. Initial phase data on PCBs, DDTs, and HCHs. Mar. Pollut. Bull. 58, 1437-1446. http://dx.doi.org/ 10.1016/j.marpolbul.2009.06.014.

Paul-Pont, I., Lacroix, C., González Fernández, C., Hégaret, H., Lambert, C., Le Goïc, N., Frère, L., Cassone, A.-L., Sussarellu, R., Fabioux, C., Guyomarch, J., Albentosa, M. Huvet, A., Soudant, P., 2016. Exposure of marine mussels Mytilus spp. to polystyrene microplastics: toxicity and influence on fluoranthene bioaccumulation. Environ. Pollut. Barking Essex 1987. http://dx.doi.org/10.1016/j.envpol.2016. 06.039.

Peliz, A., Marchesiello, P., Dubert, J., Marta-Almeida, M., Roy, C., Queiroga, H., 2007. A study of crab larvae dispersal on the Western Iberian Shelf: physical processes. J. Mar. Syst. 68, 215e236.

PlasticsEurope, 2016. Plastics - the Facts 2015 [WWW Document]. Issuu. URL https://issuu.com/plasticseuropeebook/docs/ finalplasticsthefacts2015ebookwebve (Accessed 16 February 2016).

Pommepuy, M., 1977. SAUM de la rade de Brest. Etude courantologique. Rapport préliminaire, pp.18. Retrieved from: http://archimer.ifremer.fr/doc/00055/ 16578.

R Core Team, 2016. R: A language and environment for statistical computing. $\mathrm{R}$ Foundation for Statistical Computing, Vienna, Austria. https://www.R-project. org

Reisser, J., Slat, B., Noble, K., du Plessis, K., Epp, M., Proietti, M., de Sonneville, J., Becker, T., Pattiaratchi, C., 2015. The vertical distribution of buoyant plastics at sea: an observational study in the North Atlantic Gyre. Biogeosciences 12, 1249-1256. http://dx.doi.org/10.5194/bg-12-1249-2015.

Rémy, F., Collard, F., Gilbert, B., Compère, P., Eppe, G., Lepoint, G., 2015. When microplastic is not plastic: the ingestion of artificial cellulose fibers by Macrofauna living in seagrass Macrophytodetritus. Environ. Sci. Technol. 49, 11158-11166. http://dx.doi.org/10.1021/acs.est.5b02005.

Rocha-Santos, T., Duarte, A.C., 2014. A critical overview of the analytical approaches to the occurrence, the fate and the behavior of microplastics in the environment. TrAC Trends. Anal. Chem. http://dx.doi.org/10.1016/j.trac.2014.10.011.

Rochman, C.M., Browne, M.A., Underwood, A.J., van Franeker, J.A., Thompson, R.C., Amaral-Zettler, L.A., 2016. The ecological impacts of marine debris: unraveling the demonstrated evidence from what is perceived. Ecology 97, 302-312. http://dx.doi.org/10.1890/14-2070.1.

Sá, S., Bastos-Santos, J., Araújo, H., Ferreira, M., Duro, V., Alves, F., Panta-Ferreira, B., Nicolau, L., Eira, C., Vingada, J., 2016. Spatial distribution of floating marine debris in offshore continental Portuguese waters. Mar. Pollut. Bull. 104, 269-278. http://dx.doi.org/10.1016/j.marpolbul.2016.01.011.

Salomon, J.C., Breton, M. 1991. Numerical study of the dispersive capacity of the Bay of Brest, France, towards dissolved substances. In: Lee, Cheung (Eds.), Environmental Hydraulics. Balkema, Rotterdam, pp. 459-464.

Sebille, E., van, Wilcox, C., Lebreton, L., Maximenko, N., Hardesty, B.D., Franeker, J.A van, Eriksen, M., Siegel, D., Galgani, F., Law, K.L., 2015. A global inventory of small floating plastic debris. Environ. Res. Lett. 10, 124006. http://dx.doi.org/ 10.1088/1748-9326/10/12/124006.

Sutton, R., Mason, S.A., Stanek, S.K., Willis-Norton, E., Wren, I.F., Box, C., 2016 Microplastic contamination in the san Francisco bay, California, USA. Mar. Pollut. Bull. http://dx.doi.org/10.1016/j.marpolbul.2016.05.077.

Teuten, E.L., Saquing, J.M., Knappe, D.R.U., Barlaz, M.A., Jonsson, S., Bjorn, A., Rowland, S.J., Thompson, R.C., Galloway, T.S., Yamashita, R., Ochi, D. Watanuki, Y., Moore, C., Viet, P.H., Tana, T.S., Prudente, M., Boonyatumanond, R., Zakaria, M.P., Akkhavong, K., Ogata, Y., Hirai, H., Iwasa, S., Mizukawa, K., Hagino, Y., Imamura, A., Saha, M., Takada, H., 2009. Transport and release of chemicals from plastics to the environment and to wildlife. Philos. Trans. R. Soc. B-Biol. Sci. 364, 2027-2045. http://dx.doi.org/ 10.1098/rstb.2008.0284.

Thompson, R.C., Olsen, Y., Mitchell, R.P., Davis, A., Rowland, S.J., John, A.W.G., McGonigle, D., Russell, A.E., 2004. Lost at sea: where is all the plastic? Science 304. http://dx.doi.org/10.1126/science.1094559, 838-838.

Troadec, P. Le Goff, R., 1997. Contrat de baie*: La Rade de Brest et son bassin versant Etat des lieux et des milieux. Communauté Urbaine de Brest, Brest.

Tubau, X., Canals, M., Lastras, G., Rayo, X., Rivera, J., Amblas, D., 2015. Marine litter on the floor of deep submarine canyons of the Northwestern Mediterranean Sea: the role of hydrodynamic processes. Prog. Oceanogr. 134, 379-403. http:// dx.doi.org/10.1016/j.pocean.2015.03.013.

Unger, A., Harrison, N., 2016. Fisheries as a source of marine debris on beaches in the United Kingdom. Mar. Pollut. Bull. 107, 52-58. http://dx.doi.org/10.1016/ j.marpolbul.2016.04.024.

Van Cauwenberghe, L., Vanreusel, A., Mees, J., Janssen, C.R., 2013. Microplastic pollution in deep-sea sediments. Environ. Pollut. 182, 495-499. http:// dx.doi.org/10.1016/j.envpol.2013.08.013.

Vianello, A., Boldrin, A., Guerriero, P., Moschino, V., Rella, R., Sturaro, A., Da Ros, L., 2013. Microplastic particles in sediments of Lagoon of Venice, Italy: first observations on occurrence, spatial patterns and identification. Press. Stress. Shock. Trends Estuar. Ecosyst. 130, 54-61. http://dx.doi.org/10.1016/ j.ecss.2013.03.022. 
Wesch, C., Barthel, A.-K., Braun, U., Klein, R., Paulus, M., 2016. No microplastics in benthic eelpout (Zoarces viviparus): an urgent need for spectroscopic analyses in microplastic detection. Environ. Res. 148, 36-38. http://dx.doi.org/10.1016/ j.envres.2016.03.017.

Wright, S.L., Thompson, R.C., Galloway, T.S., 2013. The physical impacts of microplastics on marine organisms: a review. Environ. Pollut. 178, 483-492. http://dx.doi.org/10.1016/j.envpol.2013.02.031.

Zettler, E.R., Mincer, T.J., Amaral-Zettler, L.A., 2013. Life in the "Plastisphere": microbial communities on plastic marine debris. Environ. Sci. Technol. 47, 7137-7146. http://dx.doi.org/10.1021/es401288x. 